\title{
ATUALIDADES
}

\section{EPIDEMIOLOGIA DO PALUDISMO NA REGIÃO DO LAGO TSANA (1)}

Nota apresentada ao Comité Permanente do Bureau Internacional de Higiene Publica, na Sessão de Outubro de 1938, pelo Professor ALDO CASTELLANI, Delegado das Colonias Italianas.

\section{CONSIDERAÇÕES GERAIS:}

Nas zonas da região de Gondar até agora visitadas, não me parece ter sido possivel constatar, durante a estação sêca, uma epidemia de paludismo. Em outras zonas do planalto africano, o paludismo limita-se ao periodo das chuvas ou ao que imediatamente as sucede.

Mesmo com referencia à região, de Gondar, póde-se afirmar com certeza, que as zonas com mais de 2.000 metros de altitude estão indenes de paludismo durante o ano inteiro, emquanto que aquelas de menor altitude, pódem ser castigadas pela epidemia durante e após as chuvas.

Azozo merece particular atenção. Aquela localidade apresenta condições semelhantes às de Kombolcia: como Kombolcia, Azozo se encontra numa altitude limite, que fixa a demarcação entre as zonas palustres e as zonas indenes. $E^{\prime}$ provavel que, como em Kombolcia, se possa constatar em Azozo uma breve epidemia de paludismo no periodo final das chuvas, e que não se possa excluir da referida região, a possibilidade do paludismo.

Para resolver tal problema de um modo certo, assim como para determinar detalhadamente as zonas palustres da'região, torna-se necessário fazer novas averiguações na época das chuvas.

No que concerne à profilaxia da proxima estação palustre, os conselhos que, segundo um ponto de vișta prático pódem ser dados, são os seguintes:

1) Nas zonas com mais de 2.000 metros de altitude, ausencia de profilaxia;

2) Nas zonas de altitude inferior a 1.600-1.700, metros, profilaxia pela quinina, dos primeiros dias de Junho até fins de Outubro. Para não aplicar quantidades inuteis de quinina, a profilaxia poderá ser feita mediante a administração de 0 gr. 60 , três dias consecutivos durante a semana. Por este método obtem-se resultados identicos aos alcançados com a administração quotidiana da mesma quantidade de quinina, e com menores incômodos.

3) Profilaxia química segundo as mesmas modalidades, a partir da segunda metade do mez de Agosto até o mez de Outubro inclusive, nas zonas que se encontram mais ou menos a 1.800 metros.

Bulletin Mensuel de l'Office International d'Hygiène Publique, Paris, 30: no. 12, Dezembro de 1938, pgs. 2793-2795.

(1) Tradução do comentário: Épidémiologie du Paludisme dans la région du Lac Tsana. 